\title{
THE EFFECT OF CROP ROTATION AND SOIL TILLAGE ON WINTER WHEAT YIELD
}

\author{
*Madara Darguza, Zinta Gaile \\ Latvia University of Life Sciences and Technologies, Latvia \\ *Corresponding author's email: madara.darguza@llu.lv
}

\begin{abstract}
Wheat (Triticum) is one of the three most important field crops used for food in the world, as well as in Latvia. The two-factorial trial was conducted at the Research and Study farm 'Pēterlauki', Latvia, with the aim to find out the effect of soil tillage and crop rotation on winter wheat grain yield formation. Two soil tillage systems (conventional and reduced), and three crop rotations with different winter wheat (Triticum aestivum) proportion in it (100, 67 and $25 \%$ ) and different fore-crops (wheat, oilseed rape (Brassica napus ssp. oleifera), faba bean (Vicia faba)) were used. Long-term trial was started in 2009, however, the data from 2016/2017, 2017/2018 and 2018/2019 growing seasons was used for this report. The highest average wheat yield was harvested in $2017\left(7.17 \mathrm{tha}^{-1}\right)$, and it was significantly $(\mathrm{p}<0.001)$ higher than yields in 2018 and 2019 (on average $6.18 \mathrm{t} \mathrm{ha}^{-1}$ and $5.68 \mathrm{t} \mathrm{ha}^{-1}$, respectively). Crop rotation with winter wheat proportion $25 \%$, in which faba bean was wheat fore-crop, showed the highest average grain yield $\left(7.35 \mathrm{t} \mathrm{ha}^{-1}\right.$ ), but the lowest yield was obtained in rotation with $100 \%$ wheat proportion (on average $5.52 \mathrm{t} \mathrm{ha}^{-1}$ ). Crop rotation scheme had a significant influence on the yield $(p<0.001)$ and 1000 grain weight $(p<0.001)$. Forecrop influenced the yield $(p<0.001)$, number of spikes per $1 \mathrm{~m}^{2}(\mathrm{p}<0.001)$, and number of grain per spike $(\mathrm{p}=0.008)$ significantly. Soil tillage did not affect the studied parameters importantly. Conditions of the trial year affected all parameters significantly.
\end{abstract}

Key words: wheat, yield formation, crop rotation, soil tillage.

\section{Introduction}

One of the most important field crops globally is wheat (Triticum), and it is ranked in the first place by harvested area in the world, and in the third place by total grain production from cereals (after rice (Oryza sativa) and maize (Zea mays)) in 2018 by the latest data from Food and Agriculture Organization of United Nations (FAOSTAT data, 2020 March, available at: http://www.fao.org/faostat/en/\#data/QC). Wheat grain is widely used for food consumption, and it is necessary to harvest high enough grain yield to feed the growing number of world population. Grain yield and its formation (values of yield components) depend directly on the growing conditions of wheat; growing conditions can be improved agronomically by choosing an appropriate soil tillage system and using thoughtful crop rotation, which also regulates soil moisture and helps to limit harmful organisms.

Crop diversification is adjusted to economic outcome, and it is affected by agricultural policy (Babulicová, 2016). Wheat yield level is at risk to decrease, while wheat is grown in rotation with a large proportion of wheat (Bonciarelli et al., 2016). The increase of wheat yield had been found in crop rotations if pulses (Babulicová, 2016), oilseeds (Schillinger \& Paulitz, 2018) or root crops (Smagacz, Kozieł, \& Martyniuk, 2016) are wheat fore-crops in the rotation. Changing the sequence of crops grown on arable land is an opportunity to increase wheat yields, and it was claimed that this increase may be up to $20 \%$ (Kirkegaard et al., 2008). Usage of wellplanned crop rotation with no repeated wheat in rotation may limit wheat leaf diseases (Mazzilli et al., 2016).
Conventional soil tillage helps to limit weeds in field (Gozubuyuk et al., 2015) and wheat leaf diseases, like tan spot (caused by Pyrenophora triticirepentis) (Cotuna et al., 2015). Conventional tillage, also named as traditional, which characterizes with comparatively deep (up to $22-30 \mathrm{~cm}$ ) soil mouldboard ploughing, is often used as soil tillage system (Rieger et al., 2008; Jug et al., 2011; Gozubuyuk et al., 2015; Hiel et al., 2018). The effect of different soil tillage systems (conventional (traditional) or reduced to varying degrees) on wheat yield was contradictory (e.g. Arvidsson, 2010; Schlegel et al., 2017) and therefore further research is needed in different environmental conditions.

M. Babulicova (2016) studied the impact of crop rotation and fore-crop (field pea (Pisum sativum), and barley (Hordeum vulgare)) on grain yield in Slovakia and found fore-crop influence on winter wheat grain yield and 1000 grain weight (TGW). Values of both were higher when field pea was used as a fore-crop. It is important to know that the diversification of crops in rotation and used soil tillage system influence not only the grain yield, but also its forming components - the number of spikes per $1 \mathrm{~m}^{2}$, number of grain per spike and TGW.

The aim of this paper was to evaluate the influence of soil tillage system and crop diversification in crop rotation on the winter wheat grain yield and its components' formation. The yield and grain quality data depending on investigated factors from two previous trial years (2016/2017 and 2018/2019) have been reported in the paper by M. Darguza \& Z. Gaile (2019). In this paper, the yield and TGW data is supplemented with the third year data, and other yield components are also analysed. 
Growing sequence of crops included in rotation (2) oilseed rape-wheat-wheat, and (3) faba bean-wheat-oilseed rape-barley in described trial years $2017-2019$

\begin{tabular}{|l|c|c|c|c|c|}
\hline \multirow{2}{*}{ Crop rotation } & \multirow{2}{*}{ Plot No. } & \multirow{2}{*}{ Crop in 2016} & \multicolumn{3}{|c|}{ Crops harvested in season } \\
\cline { 4 - 6 } & & & 2017 & 2018 & 2019 \\
\hline \multirow{2}{*}{ OR-W-W } & $1^{\text {st }}$ & w. oilseed rape & w. wheat & w. wheat & w. oilseed rape \\
\cline { 2 - 6 } & $2^{\text {nd }}$ & w. wheat & w. oilseed rape & w. wheat & w. wheat \\
\hline \multirow{3}{*}{ FB-W-OR-B } & $1^{\text {st }}$ & s. faba bean & w. wheat & w. oilseed rape & s. barley \\
\cline { 2 - 6 } & $2^{\text {nd }}$ & w. oilseed rape & s. barley & s. faba bean & w. wheat \\
\cline { 2 - 6 } & $3^{\text {rd }}$ & w. wheat & w. oilseed rape & s. barley & s. faba bean \\
\hline
\end{tabular}

w. or s. is added before crop species to identify the type of crop: w - winter or s - spring

\section{Materials and Methods}

The long-term trial was started at the Research and Study farm 'Peterlauki' $\left(56^{\circ} 30.658^{\prime} \mathrm{N}\right.$ and $23^{\circ}$ $41.580^{\prime}$ E) of Latvia University of Life Sciences and Technologies in 2009. Data analysed in this paper is from three seasons $(2016 / 2017,2017 / 2018$ and 2018/2019). The trial is two-factorial: the effect of soil tillage system and crop rotation were studied. Two soil tillage systems were applied for each crop rotation: a conventional system (CT) with mouldboard ploughing at a depth of 22-24 cm and reduced system (RT), where the disc harrowing at a depth to $10 \mathrm{~cm}$ was used. Three different variants of crop rotation were examined: rotation (1) repeated winter wheat (Triticum aestivum) sowings (W-W; wheat $100 \%$ ), rotation (2) oilseed rape (Brassica napus ssp. oleifera) - wheat - wheat (OR-W-W; wheat 67\%), rotation (3) faba bean - wheat - oilseed rape - spring barley (FB-W-OR-B; wheat 25\%). The field trial was arranged in a two-factorial split-plot design in two blocks. Each plot in every block was split in half, thus forming four replications.

Winter wheat fore-crop, as well as harvested crop in rotation (1) was always winter wheat, as it was rotation with repeated winter wheat sowings (wheat 100\%). In rotations (2) and (3), fore-crops and harvested crops (Table 1) varied from year to year. Only winter wheat yield is analysed in this paper.

Winter wheat variety used in 2016/2017 was 'Zentos', but 'Skagen' was used in 2017/2018 and $2018 / 2019$. The reason of variety change, as well as soil conditions on the site, were described in the paper by M. Darguza \& Z. Gaile, 2019. Sowing time differed depending on meteorological conditions of the trial year (Table 2). In autumn of each sowing year, complex mineral fertilizers were used at the rate: $25 \mathrm{~kg} \mathrm{~N}^{-1}, 65 \mathrm{~kg} \mathrm{P}_{2} \mathrm{O}_{5}$ ha $^{-1}$ every year, but with different $\mathrm{K}_{2} \mathrm{O}$ rates: $40 \mathrm{~kg} \mathrm{~K}_{2} \mathrm{O} \mathrm{ha}^{-1}$ was given in 2016/2017, but $65 \mathrm{~kg} \mathrm{~K}_{2} \mathrm{O} \mathrm{ha}{ }^{-1}$ - in 2017/2018 and

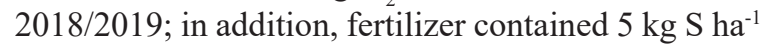
in $2016 / 2017$. Nitrogen top-dressing rate in spring was as follows: $172 \mathrm{~kg} \mathrm{~N} \mathrm{ha}^{-1}$ in 2017 , and $155 \mathrm{~kg} \mathrm{ha}^{-1}$ in 2018 and 2019; the total rate was divided into two applications (at the renewal of vegetation $86 \mathrm{~kg} \mathrm{~N} \mathrm{ha}^{-1}$, and $69-86 \mathrm{~kg} \mathrm{~N} \mathrm{ha}^{-1}$ at the GS 31-32). Control of harmful organisms in trial plots was done according to integrated cropping system, and it differed between trial years. Control was based on field monitoring data: each year the weed control was done in the spring season (Mustang Forte (10 $\mathrm{g} \mathrm{L}^{-1}$, aminopyralid, $5 \mathrm{~g} \mathrm{~L}^{-1}$, florasulam, $\left.180 \mathrm{~g} \mathrm{~L}^{-1} 2.4-\mathrm{D}\right) 0.8 \mathrm{~L} \mathrm{ha}^{-1}$ in the spring 2017 and 2018, Tombo WG (50 $\mathrm{g} \mathrm{kg}^{-1}$ pyroxulam, 25 $\mathrm{g} \mathrm{kg}^{-1}$ florasulam, $50 \mathrm{~g} \mathrm{~kg}^{-1}$ aminopyralid) $200 \mathrm{~g} \mathrm{ha}^{-1}$ + Dash 0.5 L ha-1 in 2019), the disease control by using fungicides Adexar $\left(62.5 \mathrm{~g} \mathrm{~L}^{-1}\right.$ epoxiconazole; $62.5 \mathrm{~g} \mathrm{~L}^{-1}$ fluxapyroxad) $1 \mathrm{~L} \mathrm{ha}^{-1}$ in 2017 and $2 \mathrm{~L} \mathrm{ha}^{-1}$ in 2018, Opera N (85 $\mathrm{g} \mathrm{L}^{-1}$ pyraclostrobin, $62.5 \mathrm{~g} \mathrm{~L}^{-1}$ epoxiconazole) $1 \mathrm{~L} \mathrm{ha}^{-1}$ in 2019 at GS 39-51; insecticide was used only in 2018 (Fastac $50\left(50 \mathrm{~g} \mathrm{~L}^{-1}\right.$ alpha-cypermethrin) $0.25 \mathrm{~L} \mathrm{ha}^{-1}$ ). Before winter wheat yield harvesting (at GS 87-89), sample sheets were taken for evaluation of yield components. Three sample sheets were taken from $0.125 \mathrm{~m}^{2}$ from every variant in every replication (in total 12 sample sheets from one variant). The evaluated yield components were: number of winter wheat spikes per $1 \mathbf{m}^{2}$ (counted from sample sheets and recalculated per $1 \mathrm{~m}^{2}$ ), number of grains per spike (grain was threshed from spikes in sample-sheets, then counted using equipment Contador (Pfeiffer), and divided by the number of spikes per sample sheet), winter wheat TGW ( $g$ ) was detected from harvested yield by standard method (LVS EN ISO 520:2011).

Winter wheat grain yield was harvested (see dates in Table 2) by combine (Sampo 130 (Sampo Rosenlew)) and weighted; grain purity and moisture content was detected, and then harvested yield was converted to yield with $100 \%$ purity and $14 \%$ moisture content.

Mathematical calculations of data were performed by using RStudio Multi-way Anova analysis and correlation analysis. Also, a trial year effect on winter wheat grain yield and yield components were evaluated. Bonferroni test was used to detect the significance of differences. 
Table 2

Winter wheat sowing and harvesting time, and vegetation renewal date in spring during trial years

\begin{tabular}{|l|l|l|l|}
\hline \multicolumn{1}{|c|}{ Indicators } & \multicolumn{1}{|c|}{$2016 / 2017$} & \multicolumn{1}{c|}{$2017 / 2018$} & \multicolumn{1}{c|}{$2018 / 2019$} \\
\hline Sowing time & September $19^{\text {th }}$ & September $28^{\text {th }}$ & September $6^{\text {th }}$ \\
\hline Start of vegetation period & April $14^{\text {th }}$ & April $7^{\text {th }}$ & March $15^{\text {th }}$ \\
\hline Harvesting time & August $8^{\text {th }}$ & July $24^{\text {th }}$ & ${\text { July } 29^{\text {th }}}$ \\
\hline
\end{tabular}

Table 3

Average air temperature and precipitation in trial place per trial period (2016/2017-2018/2019) and in comparison to long-term observations

\begin{tabular}{|c|c|c|c|c|c|c|c|c|}
\hline \multirow[b]{2}{*}{ Month } & \multicolumn{4}{|c|}{ Temperature, ${ }^{\circ} \mathrm{C}$} & \multicolumn{4}{|c|}{ Precipitation, $\mathrm{mm}$} \\
\hline & $\begin{array}{l}2016 / \\
2017\end{array}$ & $\begin{array}{c}2017 / \\
2018\end{array}$ & $\begin{array}{l}2018 / \\
2019\end{array}$ & $\begin{array}{l}\text { long-term } \\
\text { observation }\end{array}$ & $\begin{array}{l}2016 / \\
2017\end{array}$ & $\begin{array}{l}2017 / \\
2018\end{array}$ & $\begin{array}{l}2018 / \\
2019\end{array}$ & $\begin{array}{c}\text { long-term } \\
\text { observation }\end{array}$ \\
\hline \multicolumn{9}{|l|}{ Sowing year } \\
\hline September & 13.7 & 13.0 & 14.9 & 11.5 & 3.9 & 26.6 & 25.5 & 20.9 \\
\hline October & 5.2 & 8.0 & 8.5 & 6.7 & 18.7 & 26.7 & 10.6 & 19.3 \\
\hline November & 1.1 & 3.9 & 3.0 & 1.8 & 11.5 & 15.1 & 6.8 & 17.6 \\
\hline \multicolumn{9}{|c|}{ Harvesting year } \\
\hline March & 3.2 & -1.8 & 3.0 & -1.5 & 30.6 & 10.8 & 29.6 & 31.3 \\
\hline April & 4.8 & 9.0 & 8.1 & 5.3 & 38.5 & 47.2 & 8.1 & 40.0 \\
\hline May & 11.5 & 16.1 & 12.3 & 11.7 & 23.5 & 20.8 & 20.4 & 51.4 \\
\hline June & 15.1 & 16.8 & 19.4 & 15.4 & 49.5 & 15.2 & 8.6 & 75.3 \\
\hline July & 16.6 & 20.8 & 16.8 & 16.6 & 83.0 & 33.6 & 101.0 & 81.7 \\
\hline August & 16.8 & 19.4 & 17.6 & 16.2 & 31.0 & 28.4 & 37.8 & 73.7 \\
\hline
\end{tabular}

Meteorological data in trial years differed considerably according to the precipitation and temperature (Table 3). Meteorological situation favoured high winter wheat grain yield formation in 2017, but adverse conditions for winter wheat growth and development were observed in 2018 and 2019.

The season 2016/2017 started with warm weather and low precipitation in September and continued with optimal growing temperatures for plants, which was close to indicators of long-term observations, but the total amount of precipitation in spring season was lower, if compared to long-term observations. Season 2017/2018 differed from others with the highest amount of precipitation in autumn period, which was the reason of delayed sowing time (Table 3), and it had an impact on growing and development of wheat till the end of vegetation. In spring 2018, air temperature was higher than long-term average observations and it continued to be higher till harvesting, which led to shortening of vegetation period and faster ripening of grain. The amount of precipitation from May till harvesting was low. Plants suffered from lack of moisture at important growth stages (like tillering, spike formation and grain filling), and it influenced yield formation and decreased yield. The third trial season 2018/2019 continued with lack of moisture during sowing, and wheat germination started only three weeks after sowing, when precipitation was observed; rain made soil crust and it led to lowered field germination. In the spring 2019, vegetation season started early - in the middle of March (Table 3); however, lack of moisture was still observed in soil, since low precipitation was observed even during the winter. Precipitation was low also in April, May and June 2019, when important yield components formed. Drought decreased winter wheat yield.

\section{Results and Discussion}

Winter wheat grain yield was significantly $(p<0.001)$ affected by crop rotation, fore-crop and year conditions. The highest average grain yield was harvested from rotation (3) FB-W-OR-B $\left(7.35 \mathrm{t} \mathrm{ha}^{-1}\right)$, but the lowest - from rotation (1) W-W (5.52 $\left.\mathrm{t} \mathrm{ha}^{-1}\right)$ (Figure 1). Significant yield difference at $95 \%$ probability level was not found $(p=0.47)$, whether the fore-crop was oilseed rape $\left(6.98 \mathrm{t} \mathrm{ha}^{-1}\right)$ or faba bean $\left(7.35 \mathrm{t} \mathrm{ha}^{-1}\right)$. Used soil tillage treatment did not affect average wheat grain yield per trial period significantly $(\mathrm{p}=0.277)$. Significant differences $(p<0.001)$ of wheat yields were observed depending 


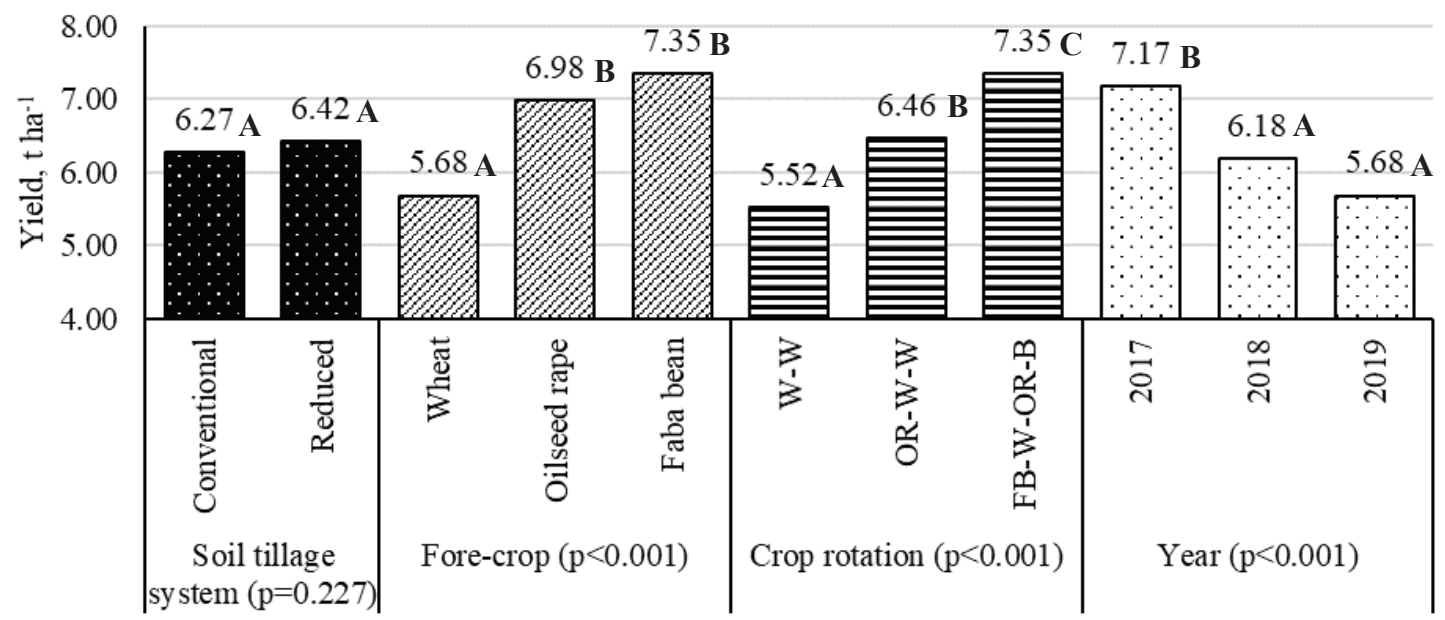

Figure 1. The grain yield of winter wheat depending on researched factors, $t \mathrm{ha}^{-1}: \mathrm{W}-\mathrm{W}-\mathrm{wheat} 100 \%$ in rotation; $\mathrm{W}-\mathrm{W}-\mathrm{OR}$ - wheat $67 \%$ in rotation; FB-W-OR-B - wheat $25 \%$ in rotation. Significantly different means for each factor are marked with different letters A, B, C.

on conditions in the trial year. The highest average grain yield $\left(7.17 \mathrm{t} \mathrm{ha}^{-1}\right)$ was obtained in 2017 , when the meteorological situation was most favourable for wheat yield formation if compared to two following crop years $(2018,2019)$.

A positive effect of fore-crop from Leguminosae family has been found by $M$. Babulicova, when wheat was grown after pea, and the obtained yield was higher, if compared to that obtained after cereal fore-crop (Babulicova, 2016). J.F. Angus et al. (2015) reported that non-cereal wheat fore-crop provided an increase in wheat grain yield, e.g., if oilseed rape was grown before wheat, or even a higher yield increase has been found if fore-crops were grain legumes; the yield increase varied from $20 \%$ after oilseed rape to $60 \%$ increase after legumes. It is also claimed that if fore-crop was oilseed rape, there is a positive influence on the second year wheat yield.

Soil tillage system effect on wheat yield is small. Results did not show significant yield differences, when different soil tillage systems were compared in clay and clay loam soil in the United Kingdom (with different tillage depth from $200 \mathrm{~mm}$ and less) (Giannitsopoulos, Burgess, \& Rickson, 2019). Our

\section{Number of winter wheat spikes per $1 \mathbf{~ m}^{2}$ depending on researched factors}

\begin{tabular}{|c|c|c|c|c|}
\hline \multirow{2}{*}{ Factors } & \multicolumn{3}{|c|}{ Year $(\mathrm{p}<0.001)$} & \multirow{2}{*}{ Average } \\
\hline & 2017 & 2018 & 2019 & \\
\hline \multicolumn{5}{|l|}{ Crop rotation $(\mathrm{p}=0.335)$} \\
\hline W-W & $542^{\mathrm{a}}$ & $534^{\mathrm{a}}$ & $383^{\mathrm{a}}$ & $486^{\mathrm{A}}$ \\
\hline W-W-OR & $547^{\mathrm{a}}$ & $528^{\mathrm{a}}$ & $372^{\mathrm{a}}$ & $494^{\mathrm{A}}$ \\
\hline FB-W-OR-B & $586^{\mathrm{a}}$ & - & $451^{\mathrm{a}}$ & $519^{\mathrm{A}}$ \\
\hline \multicolumn{5}{|l|}{ Fore-crop $(\mathrm{p}<0.001)$} \\
\hline wheat & $542^{\mathrm{a}}$ & $527^{\mathrm{a}}$ & $377^{\mathrm{a}}$ & $470^{\mathrm{A}}$ \\
\hline oilseed rape & $547^{\mathrm{a}}$ & $537^{\mathrm{a}}$ & - & $541^{\mathrm{B}}$ \\
\hline faba bean & $586^{\mathrm{a}}$ & - & $451^{\mathrm{b}}$ & $519^{\mathrm{AB}}$ \\
\hline \multicolumn{5}{|l|}{ Soil tillage system $(\mathrm{p}=0.824)$} \\
\hline conventional & $549^{\mathrm{a}}$ & $556^{\mathrm{a}}$ & $391^{\mathrm{a}}$ & $499^{\mathrm{A}}$ \\
\hline reduced & $567^{\mathrm{a}}$ & $504^{\mathrm{a}}$ & $413^{\mathrm{a}}$ & $495^{\mathrm{A}}$ \\
\hline Average depending on trial year & $558^{\mathrm{B}}$ & $530^{\mathrm{B}}$ & $402^{\mathrm{A}}$ & $x$ \\
\hline
\end{tabular}

$\mathrm{W}-\mathrm{W}$ - wheat $100 \%$ in rotation; $\mathrm{W}-\mathrm{W}-\mathrm{OR}$ - wheat $67 \%$ in rotation; FB-W-OR-B - wheat $25 \%$ in rotation. Significantly different means for each factor are marked with different letters in superscript: $\mathrm{A}, \mathrm{B}$ - significant difference for average number of winter wheat spikes of three trial years and means on factor graduations; ${ }^{\text {a }}{ }^{\text {b }}$ - significant difference in specific trial year. 
results were similar and also obtained in clay soil, and they also match with A.J. Schlegel et al. (2017), who reported that average winter wheat yield was higher in variants, where no-till and reduced tillage systems were used if compared to CT, but yields were not significantly different between variants, where different tillage systems were used in half of the trial years (Schlegel et al., 2017). Reduced tillage system has proved its advantages under rainfed conditions if compared to the CT system to get higher wheat grain yields (Pittelkow et al., 2015).

The winter wheat yield component 'number of spikes per $1 \mathrm{~m}^{2}$, was moderate on average per trial years 497 (402-558; Table 4), and it was significantly $(\mathrm{p}<0.001)$ affected by fore-crop and the year. Crop rotation $(p=0.335)$ and soil tillage system $(p=0.824)$ did not affect this yield component significantly.

Higher number of spikes per $1 \mathrm{~m} 2$ on average was obtained, when wheat was grown after faba bean or oilseed rape. When analysing the results of each year separately, significant differences in average number of spikes per $1 \mathrm{~m}^{2}$ were not found, when the values of 2017 and 2018 were compared. In addition, forecrop similarly to crop-rotation and soil tillage system also did not affect values of this yield component significantly in 2017 and 2018. Significant difference $(\mathrm{p}<0.020)$ in number of spikes per $1 \mathrm{~m}^{2}$ was found in 2019 between variants, where fore-crop was wheat (377) and faba bean (451); these results influenced the average values during three year trial period. The lowest average number of spikes per $1 \mathrm{~m}^{2}$ was observed in 2019 (402) due to low field germination and poor tillering caused by drought. The calculated average field germination of winter wheat was $64 \%$ in 2018/2019. Meteorological conditions during germination were characterised by a low amount of productive precipitation, and another obstructive factor was soil crust, which formed after the rain in clay soil. As drought continued in autumn, winter and even next spring (Table 3), tillering, which can increase the number of spikes per $1 \mathrm{~m}^{2}$, was poor.

It was reported by Vyn et al. (1991) that the number of wheat spikes per $1 \mathrm{~m}^{2}$ is higher if other than wheat crop is sown before wheat in crop rotation (Vyn, Sutton, \& Raimbault, 1991). The number of spikes depending on different fore-crops has been studied also in the USA, and it was reported that significantly higher number of wheat spikes per $1 \mathrm{~m}^{2}$ was found after oat-pea mixture if compared to the variant, where spring wheat was used as fore-crop; the lowest number of spikes per $1 \mathrm{~m}^{2}$ was found, when wheat fore-crop was soybean (Anderson, 2008). A soil tillage impact on plant density was found in Croatia in chernosem; higher plant density was found in variants, where shallow tillage (till $15 \mathrm{~cm}$ depth) was used if compared with the traditional tillage system, also soil tillage and year interaction was found (Jug et al., 2011).

Correlation analysis showed a moderate positive relation between the number of spikes per $1 \mathrm{~m}^{2}$ and yield $\left(\mathrm{r}=0.543>\mathrm{r}_{0.05}=0.234, \mathrm{n}=72\right)$.

The number of grains per spike differed significantly depending on a trial year $(\mathrm{p}<0.001)$ and fore-crop $(\mathrm{p}=0.008)$, and it varied from 26.4 in 2017 to 34.1 in 2019 (Table 5).

\section{Number of grain per spike of winter wheat depending on researched factors}

\begin{tabular}{|c|c|c|c|c|}
\hline \multirow{2}{*}{ Factors } & \multicolumn{3}{|c|}{ Year $(\mathrm{p}<0.001)$} & \multirow{2}{*}{ Average } \\
\hline & 2017 & 2018 & 2019 & \\
\hline \multicolumn{5}{|l|}{ Crop rotation $(\mathrm{p}=0.312)$} \\
\hline W-W & $25.3^{\mathrm{a}}$ & $31.7^{\mathrm{a}}$ & $33.6^{\mathrm{a}}$ & $30.2^{\mathrm{A}}$ \\
\hline W-W-OR & $25.1^{\mathrm{a}}$ & $32.5^{\mathrm{a}}$ & $32.8^{\mathrm{a}}$ & $30.8^{\mathrm{A}}$ \\
\hline FB-W-OR-B & $28.7^{\mathrm{a}}$ & - & $35.8^{\mathrm{a}}$ & $32.3^{\mathrm{A}}$ \\
\hline \multicolumn{5}{|l|}{ Fore-crop $(\mathrm{p}=0.008)$} \\
\hline wheat & $25.3^{\mathrm{a}}$ & $32.2^{\mathrm{a}}$ & $33.3^{\mathrm{a}}$ & $31.2^{\mathrm{A}}$ \\
\hline oilseed rape & $25.1^{\mathrm{a}}$ & $32.3^{\mathrm{a}}$ & - & $28.7^{\mathrm{B}}$ \\
\hline faba bean & $28.7^{\mathrm{a}}$ & - & $35.8^{\mathrm{a}}$ & $32.3^{\mathrm{A}}$ \\
\hline \multicolumn{5}{|l|}{ Soil tillage $\operatorname{system}(\mathrm{p}=0.164)$} \\
\hline conventional & $26.3^{\mathrm{a}}$ & $30.6^{\mathrm{a}}$ & $37.9^{\mathrm{b}}$ & $31.6^{\mathrm{A}}$ \\
\hline reduced & $26.4^{\mathrm{a}}$ & $33.9^{\mathrm{b}}$ & $30.3^{\mathrm{a}}$ & $30.2^{\mathrm{A}}$ \\
\hline Average depending on trial year & $26.4^{\mathrm{B}}$ & $32.2^{\mathrm{A}}$ & $34.1^{\mathrm{A}}$ & $x$ \\
\hline
\end{tabular}

$\mathrm{W}-\mathrm{W}$ - wheat $100 \%$ in rotation; $\mathrm{W}-\mathrm{W}-\mathrm{OR}$ - wheat $67 \%$ in rotation; FB-W-OR-B - wheat $25 \%$ in rotation. Significantly different means for each factor are marked with different letters in superscript: ${ }^{\mathrm{A}, \mathrm{B}}$ - significant difference for number of gains per spike of winter wheat of three trial years and means on factor graduations; ${ }^{a}, \mathrm{~b}$ - significant difference in specific trial year. 


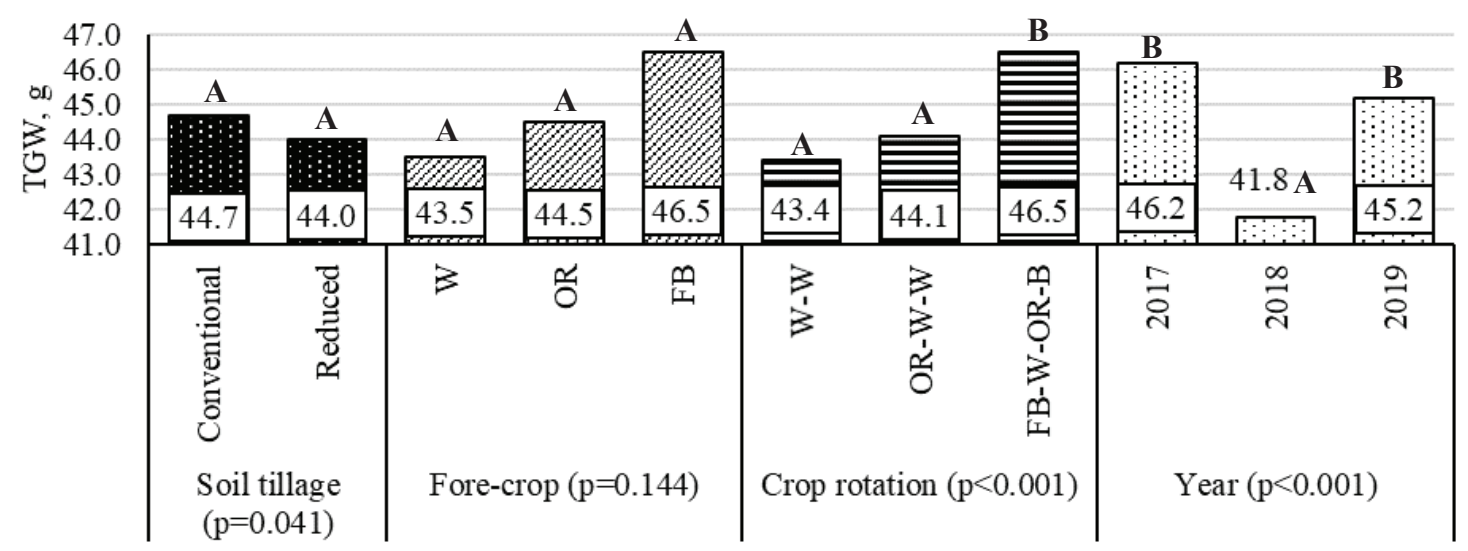

Figure 2. Winter wheat thousand grain weight (g) depending on researched factors: $\mathrm{W}-\mathrm{W}$ - wheat $100 \%$ in rotation; $\mathrm{W}-\mathrm{W}-\mathrm{OR}$ - wheat $67 \%$ in rotation; FB-W-OR-B - wheat $25 \%$ in rotation. Significantly different thousand grain weight $(\mathrm{g})$ means for each factor are marked with different letters: A, B.

The difference found in the average number of grain per spike depending on fore-crops, namely when fore-crop was oil-seed rape - can be explained by data set; oilseed rape was fore-crop for wheat grown in 2017 and 2018, when the number of grain per spike on average was lower. Significantly lower $(p<0.001)$ number of grain per spike was gained in 2017, when the highest number of spikes per $1 \mathrm{~m}^{2}$ was observed and the highest grain yield was harvested. Correlation coefficient showed a moderate negative relation between the number of grain per spike and number of spikes per $1 \mathrm{~m}^{2}\left(\mathrm{r}=|-0.505|>\mathrm{r}_{0.05}=0.234, \mathrm{n}=72\right)$ per three-year trial period, and in the season 2017/2018 $\left(\mathrm{r}=|-0.555|>\mathrm{r}_{0.05}=0.404, \mathrm{n}=24\right)$ if calculation was done using data of each trial year separately. In R.L. Anderson's trials, a significant difference between the number of grain per spike depending on fore-crop (higher after soybean) was also found, and similarly the number of grain per spike was higher in cases with lower tiller density (Anderson, 2008), but significant difference in values of this parameter was not found, when fore-crops were maize and oilseed rape (Rieger et al., 2008). Influence of soil tillage system on the number of grain per spike was not found also by other researchers, when traditional and reduced tillage systems were compared (Rieger et al., 2008; Jug et al., 2011).

TGW was significantly influenced by a crop rotation scheme $(\mathrm{p}<0.001)$ and trial year $(\mathrm{p}<0.001)$ (Figure 2). TGW has a dual nature - it is a yield component, as well as an indicator of grain quality. TGW in 2017 and 2018 was described in detail as an indicator of grain quality in our previous paper (Darguza \& Gaile, 2019).

The average TGW of wheat grown in crop rotation (3) FB-W-OR-B was significantly higher (46.5 g) if compared with other two rotations. Mathematically significant differences were not found between average TGW values depending on fore-crop in 2019; however, in years 2017 and 2018, it was found that in cases, when fore-crop was oil-seed rape or faba bean, winter wheat showed higher TGW. TGW was $3 \mathrm{~g}$ higher if wheat was grown after faba bean ( $\mathrm{p}$ $<0.001$ ), and $1.6 \mathrm{~g}$ higher if fore-crop was oilseed rape $(\mathrm{p}=0.424)$ in comparison with the variant where wheat was fore-crop. The highest average TGW was noted in 2017 (46.2 g; Figure 2), when the weather conditions (namely amount of precipitation) during grain formation and filling were more favourable if compared with other two years. Similar results, when significantly higher TGW of wheat was obtained in the variant with pea as fore-crop if compared with barley as fore-crop have been found in Slovakia (Babulicova, 2016); similarly to our trial also significant differences of TGW values between trial years were noted. TGW differences between variants were not found if forecrops were maize or oilseed rape (Rieger et al., 2008). In our trial, a positive weak correlation was found between TGW and wheat yield $\left(r=0.405>r_{0.05}=0.234\right.$, $n=72$ ), when data of three years were used, and a positive moderate correlation between these two indicators was found also in specific trial years: in $2017\left(\mathrm{r}=0.666>\mathrm{r}_{0.05}=0.404, \mathrm{n}=24\right)$ and in 2018 $\left(\mathrm{r}=0.559>\mathrm{r}_{0.05}=0.404, \mathrm{n}=24\right)$. I.A. Cociu \& E. Alionte (2011) reported that TGW very strongly correlated with grain yield.

Different soil tillage systems did not influence TGW (Figure 2), and similar results were found also by other researchers (Ozpinar, 2006; Cociu \& Alionte, 2011; Jug et al., 2011). S. Rieger et al. found that TGW did not differ between CT and minimal tillage variants, but it was mathematically lower in zero tillage variant (Rieger et al., 2008). 


\section{Conclusions}

Crop rotation scheme had a significant influence on yield and TGW, and the highest values of these parameters were obtained in four-crop rotation (faba bean - winter wheat - oil-seed rape - barley). Forecrop affected yield and number of spikes per $1 \mathrm{~m}^{2}$ significantly, and higher average values were obtained after oil-seed rape and faba beans as fore-crops; forecrop affected also average per trial period number of grain per spike significantly, but interpretation of specific values of this parameter should be found during next trial years. Soil tillage did not affect any of the studied parameters on average per three-year trial period significantly. All studied parameters were affected significantly by the conditions of trial years.

\section{Acknowledgements}

The study was financed by Ministry of Agriculture project 'Influence of minimal soil tillage on its fertility maintenance, development and distribution of pests as well as crops' yield and quality in resowings' and LLU project Z33.

\section{References}

Anderson, R.L. (2008). Growth and yield of winter wheat as affected by preceding crop and crop management. Agronomy Journal, 100, 977-980. DOI: 10.2134/agronj2007.0203.

Angus, J.F., Kirkegaard, J.A., Hunt, J.R., Ryan, M.H., Ohlander, L., \& Peoples, M.B. (2015). Break crops and rotations for wheat. Crop and Pasture Science, 66(6), 523-552. DOI: 10.1071/CP14252.

Arvidsson, J. (2010). Energy use efficiency in different tillage systems for winter wheat on a clay and silt loam in Sweden. European Journal of Agronomy, 33(3), 250-256. DOI: 10.1016/J.EJA.2010.06.003.

Babulicová, M. (2016). Enhancing of winter wheat productivity by the introduction of field pea into crop rotation. Agriculture, 62(2), 101-110. DOI: 10.1515/agri-2016-0011.

Bonciarelli, U., Onofri, A., Benincasa, P., Farneselli, M., Guiducci, M., Pannacci, E., Tosti, G., \& Tei, F. (2016). Long-term evaluation of productivity, stability and sustainability for cropping systems in Mediterranean rainfed conditions. European Journal of Agronomy, 77, 146-155. DOI: 10.1016/j.eja.2016.02.006.

Cociu, A.I., \& Alionte, E. (2011). Yield and some quality traits of winter wheat, maize, and soybean, grown in different tillage and deep loosening systems aimed to soil conservation. Romania Agricultural Research, $28,109-120$.

Cotuna, O., Paraschivu, M., Paraschivu, A., \& Saratelanu, V. (2015). The influence of tillage, crop rotation and residue management on tan spot (Drechslera Tritici Repentis Died. Shoemaker) in winter wheat. Research Journal of Agricultural Science, 47(2), 13-21.

Darguza, M., \& Gaile, Z. (2019). Yield and quality of winter wheat, depending on crop rotation and soil tillage. In Annual $25^{\text {th }}$ International Scientific Conference 'Research for Rural Development-2019' Proceedings, 15-17 May 2019, Vol. 2 (pp. 29-35). Jelgava, Latvia: Latvia University of Life Sciences and Technologies. DOI: $10.22616 /$ rrd.25.2019.045.

Giannitsopoulos, M.L., Burgess, P.J., \& Rickson, R.J. (2019). Effects of conservation tillage systems on soil physical changes and crop yields in a wheat-oilseed rape rotation. Journal of Soil and Water Conservation 2019, 74(3), 247-258. DOI: 10.2489/jswc.74.3.247.

Gozubuyuk, Z., Sahin, U., Adiguzel, M.C., Ozturk, I., \& Celik, A. (2015). The influence of different tillage practices on water content of soil and crop yield in vetch-winter wheat rotation compared to fallowwinter wheat rotation in a high altitude and cool climate. Agricultural Water Management, 160, 84-97. DOI: 10.1016/J.AGWAT.2015.07.003.

Hiel, M.P., Barbieux, S., Pierreux, J., Olivier, C., Lobet, G., Roisin, C., Roisin, C., Garré, S., Colinet, G., Bodson, B., \& Dumont, B. (2018). Impact of crop residue management on crop production and soil chemistry after seven years of crop rotation in temperate climate, loamy soils. PeerJ, 6, e4836. DOI: 10.7717/peerj.4836.

Jug, I., Jug, D., Sabo, M., Stipešević, B., \& Stošić, M. (2011). Winter wheat yield and yield components as affected by soil tillage systems. Turkish Journal of Agriculture and Forestry, 35(1), 1-7. DOI: 10.3906/ tar-0909-376.

Kirkegaard, J., Christen, O., Krupinsky, J., \& Layzell, D. (2008). Break crop benefits in temperate wheat production. Field Crops Research, 107 (3), 185-195. DOI: 10.1016/j.fcr.2008.02.010.

Mazzilli, S.R., Ernst, O.R., de Mello, V.P., \& Pérez, C.A. (2016). Yield losses on wheat crops associated to the previous winter crop: Impact of agronomic practices based on on-farm analysis. European Journal of Agronomy, 75, 99-104. DOI: 10.1016/j.eja.2016.01.007.

Ozpinar, S. (2006). Effects of tillage on productivity of a winter wheat-vetch rotation under dryland Mediterranean conditions. Soil and Tillage Research, 89(2), 258-265. DOI: 10.1016/j.still.2005.07.009.

Pittelkow, C.M., Linquist, B.A., Lundy, M.E., Liang, X., van Groenigen, K.J., Lee, J., van Gestel, N., Six, J., Venterea, R.T., \& van Kessel, C. (2015). When does no-till yield more? A global meta-analysis. Field Crops Research, 183, 156-168. DOI: 10.1016/j.fcr.2015.07.020. 
Rieger, S., Richner, W., Streit, B., Frossard, E., \& Liedgens, M. (2008). Growth, yield, and yield components of winter wheat and the effects of tillage intensity, preceding crops, and $\mathrm{N}$ fertilisation. European Journal of Agronomy, 28(3), 405-411. DOI: 10.1016/j.eja.2007.11.006.

Schillinger, W.F., \& Paulitz, T.C. (2018). Canola versus wheat rotation effects on subsequent wheat yield. Field Crops Research, 223, 26-32. DOI: 10.1016/J.FCR.2018.04.002.

Schlegel, A.J., Assefa, Y., Haag, L.A., Thompson, C.R., \& Stone, L. (2017). Long-term Tillage on Yield and Water Use of Grain Sorghum and Winter Wheat. Agronomy Journal, 110(1), 269-280. DOI: 10.2134/ agronj2017.02.0104.

Smagacz, J., Kozieł, M., \& Martyniuk, S. (2016). Soil properties and yields of winter wheat after long-term growing of this crop in two contrasting rotations. Plant Soil Environ., 62, 566-570. DOI:10.17221/582/2016PSE.

Vyn, J., Sutton, J.C., \& Raimbault, B.A. (1991). Crop sequence and tillage effects on winter wheat development and yield. Canadian Journal of Plant Science, 676(71), 669-676. DOI: 10.4141/cjps91-099. 